\title{
COMPLAINT HANDLING THROUGH SOCIAL MEDIA: PERCEIVED JUSTICE AND CUSTOMER SATISFACTION
}

\author{
Made Dwita Juliarta, Achmad Nizar Hidayanto, Ave Adriana Pinem and Putu Wuri Handayani \\ Faculty of Computer Science, Universitas Indonesia \\ Kampus UI, Depok, Indonesia
}

\begin{abstract}
Nowadays, it is common for us to complaint about the service or product by using social media platform. Organizations are usually having their customer service or public relation to maintain their social media account such as Twitter, Instagram, Facebook or other platforms. This study aims to analyze perceived justice in complaint handling process through social media and its impact towards customer satisfaction. Customer satisfaction is evaluated together with trust and perceived product quality for their influence in e-WOM and continues usage. The sample of the study is customer of a telecommunication company who is the follower of its customer care account in Twitter. The questionnaires were distributed online, and 238 valid response were analyzed using CB-SEM. The results show that, customers would be satisfied if the complaint handling process is accurate and quick (procedural justice) and supported by compensation (distributive justice). The satisfaction would increase customer trust and perceived product quality and eventually increase their intention to continue using the service and spread positive e-WOM.
\end{abstract}

\section{KEYWORDS}

Perceived Justice, Satisfaction, Trust, Perceived Product Quality, e-WOM, Continues Usage

\section{INTRODUCTION}

In this era where the technology advancement is rapidly growing, and market transparency is increasingly high, and technology is growing rapidly, customer needs continue to increase, and their long-term loyalty is a difficult to achieve. Therefore, companies need a greater effort to improve their relationships with customer. Complaint handling management holds a key position, because it helps restore customer satisfaction and returns the customer's desire to repurchase (Johannsen \& Zellner, 2015). Complaints submitted by customers are an indicator that one or more of the services provided does not work as they should. Effective complaint handling can change customers who feel disadvantaged to be more satisfied and become loyal customers. The main determinants of customer satisfaction in handling complaints perceived justice which are procedural, distributive, and interactional justice (Brock, et al., 2013). Perceived justice is identified as the main concept in the organization's response to handling service failures (Ding \& Lii, 2016).

Nowadays, it is common for us to complaint about the service or product by using social media platform. Organizations are usually having their customer service or public relation to maintain their social media account such as Twitter, Instagram, Facebook or other platforms. Additionally, with the emergence of e-commerce, the sales of some services can be conducted easily using application without meeting directly with the customer. For example, the service provided by telecommunication company. Customer can top up their phone credit using mobile banking, or purchase internet data package through application. Thus, when having problem using the service, it is easier for customer to contact the provider using social networking sites.

In this study, we would like to assess the complaints handling process through social media and evaluate the perceived justice and satisfaction relationship. In handling conventional complaints where customers are handled directly through telephone lines and or face to face with complaints handling agents, perceived justice becomes an important thing to achieve customer satisfaction. There is a significant relationship between the four dimensions of perceived justice to customer satisfaction (Ding \& Lii, 2016). While in this study, we would like to focus on the media for complaint handling which is social media that has a difference 
with the handling of conventional complaints. We also want to evaluate the impact of satisfaction towards trust, product quality, e-WOM and continuous usage. Previous researches had been conducted to study e-WOM and repurchase intention and both are influenced by customer satisfaction and trust. From the existing studies, the authors have not found any studies that discuss the effect of customer satisfaction and trust on perceived product quality. Therefore, we would like to evaluate the relationship between customer satisfaction and trust to perceived product quality as well as the relationship between perceived product quality and the concept of e-WOM and repurchase intention.

\section{THEORITICAL BACKGROUND AND HYPOTHESIS DEVELOPMENT}

\subsection{Perceived Justice}

Perceived Justice is the fairness that perceive by customers when they involved in the service recovery procedures in the communication and interpersonal activities, and it is the main antecedents in customer evaluation (Ding \& Lii, 2016). And according to Adams (1965), perceived justice refers to the extent to which customers feel fairly treated during failures handling and service recovery (Ding \& Lii, 2016). There are three dimensions of perceived justice, namely; distributive justice, procedural justice and interactional justice (Ding \& Lii, 2016).

Distributive justice is an attribute that focuses on results and solutions of a problem. The solutions depict organization effort to compensate customer loss even if it occurs cost for the organization. This can be reflected by giving compensation to customers who experienced problem in using service or product. Distributive justice has a significant influence on the consumers' word of mouth. Procedural justice is an attribute that focuses on righteousness that should be accepted by consumers when filing complaints in accordance with the rules and policies set by the company. Procedural justice includes process control, decision control, accessibility, timing/speed, and flexibility when handling customer complaints. The third dimension is interactional justice that concerns to the matters relating to the response given by the organization to consumers in providing services on complaint handling. When the customer received good response from the organization, it will improve customer satisfaction with the services provided by the company. There are two types interactional justice namely: Interpersonal Justice and Informational Justice. Interpersonal Justice refers to the extent to which customers are treated with courtesy and respect by the organization or employees involved in implementing service recovery procedures. While Informational Justice focuses on whether consumers receive adequate and appropriate explanations in the recovery of services and/or handling complaints that they submitted (Ding \& Lii, 2016).

\subsection{Satisfaction, Trust, e-WOM, and Research Gap}

Satisfaction is a pleasure or disappointment that initiates from a comparison between expectation and actual performance of a product or service (Kotler, 2009). Highly satisfied customers usually stay loyal for longer periods of time and make another purchase when the company introduces new products or launches the updated products. These customers will also share the positive information about the company and its products to others and do not pay much attention in competing brands, and more importantly they are not too sensitive about prices charged by the company. Satisfaction is especially crucial to be maintained when customer has bad experience or file a complaint regarding the product or service. The process in complaint handling can affect customer satisfaction and eventually determine their intention to repurchase and to spread the word-of-mouth. It depends on how the justice is perceived by the customer (Wirtz \& Matilla, 2004).

Trust is defined as a phycological state to be open to vulnerability based on favorable expectation or behavior of other party (Fang, et al., 2016). In an online platform trust would be more difficult to gain since there are no direct interaction between to parties. e-WOM (electronic word of mouth) is a statement made by actual, potential consumers or previous consumers about a product or company that available in the internet (Hennig-Thurau, et al., 2004). e-WOM would increase transparency of a product or service, in other words consumers have a higher active role in the value chain cycle so consumers are able to influence products and prices based on individual preferences (Park \& Kim, 2008). 
Previous study had been conducted to evaluate the impact of perceived justice on customer satisfaction in the context of service failures in online games (Ding \& Lii, 2016), in B2B context (Brock, et al., 2013), and hospitality industry (Karatepe, 2006). However, with the emergence of complaint handling through social media in telecommunication industry still difficult to find. On the other scope, other researches had been conducted to prove the impact of satisfaction towards trust, also the impact of trust toward Word-Of-Mouth (WOM) and repurchase intention in online shopping context (Fang, et al., 2016), in complaint handling process of an online games (Ding \& Lii, 2016). Thus, perceived justice, satisfaction, trust, e-WOM and repurchase intention are captured in one picture on how complaint handling process, which supposed to be a disadvantage condition, if managed fairly will be profitable to the organization. Then research by (Bao, 2015) states that the desire of customers to continue to use services is significantly influenced by the level of customer satisfaction with service, product quality and product prices. The perception of good product quality will keep customers loyal using the products offered by the company. Hence, the perceived product quality will also be evaluated in this study on its relationship with satisfaction, trust, e-WOM and continuous usage.

\subsection{Hypothesis Development}

Based on previous studies and previous literatures, we develop conceptual model depicts thirteen hypotheses shown in Figure 1.

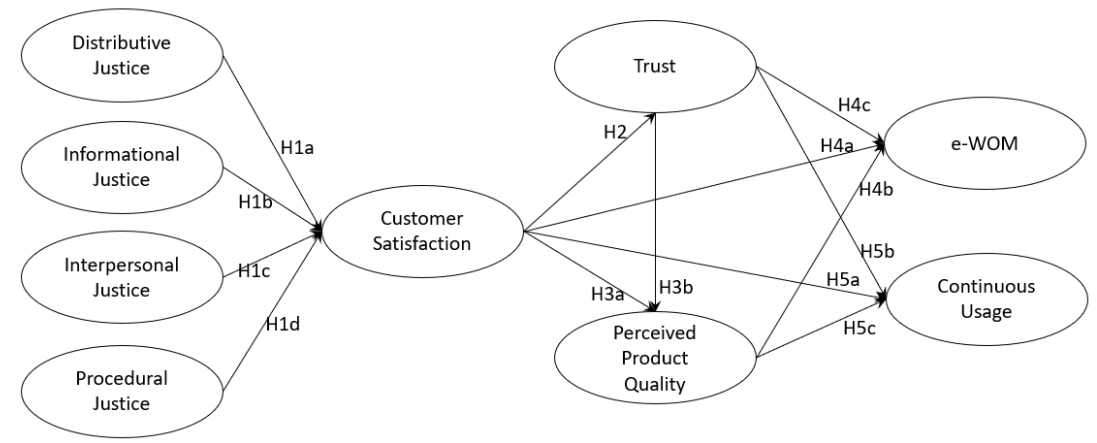

Figure 1. Conceptual Model

In complaint handling process, action and complement given to customers after they report the case will affects the level of customer satisfaction. Distributive Justice is an effort made by a company to allocate resources in fixing the service failures and focusing on compensation. If customer complaints are handled by providing appropriate compensation, the satisfaction will be achieved. In this study, we focused in complaint handling conducted through social media, thus the distributive justice given by company can be in a form of discounts or refunds to achieve higher level of satisfaction (Ding \& Lii, 2016).

Informational Justice represented by an adequate explanation that in accordance with the reported complaints or company service improvement. In this context, customers want to understand what is happening, what the cause is, and what do the company is doing to deal with failure. An informative explanation is quite effective in helping customers and often used as complaints handling strategies. When a failure occurs, if the customers do not get enough information, they will assume that the process is unfair. We proposed that adequate information provided through social media influences customer satisfaction when they report a complaint. When customers get enough information, they will not wary to continuing next purchase and not chose other vendor and when a company offers adequate and specific explanations to customers, their satisfaction is increased during the service recovery process (Nikbin, et al., 2012).

Interpersonal justice is perceived when company focuses on treating the customer politely and respectfully when handling their complaints. In social media, although there is no face to face interaction with customers in handling complaints, interpersonal justice can still also be achieved with respectful comment or replies given to the customers. This interaction has a positive influence on customer satisfaction in handling complaints process (Tax, et al., 1998). 
Procedural justice is the fairness perceived in specific policies, processes, and methods adopted by the company to deal with service issues and service failures restoration including timeliness, accessibility, control processes, and flexibility to adapt to customer needs. This procedural justice also includes accuracy, speed and procedures in matters of service handling and recovery. We proposed that the accuracy and speed in answering and/or resolving customer complaints through social media platforms is an important aspect to keep customer satisfied. In accordance with above explanations, the authors propose the research hypothesis as follows:

H1a: Distributive justice in complaints handling process through social media has positive impact on customer satisfaction

H1b: Informational justice in complaints handling process through social media has positive impact on customer satisfaction

H1c: Interpersonal justice in complaints handling process through social media has positive impact on customer satisfaction

H1d: Procedural justice in complaints handling process through social media has positive impact on customer satisfaction

In this study, customer satisfaction is particularly defined by the satisfaction perceived by customers when complaint handling process is ongoing and comes from the contentment of how the provider handles their complaints. When customers are satisfied with response given by customer service staff during the time, then the level of customer trust to the companies will increase. The staff response is the reflection of company's concern toward customer satisfaction. Thus, customer service and complaint handling agent are one of the frontlines that must be trained to communicate well with customers. If the level of customer satisfaction increases, then the level of customer trust also increases. Customer satisfaction with service providers can build customer trust. In the context of consumer behavior, trust is defined as an achievement of the level of satisfaction and loyalty that results from problem handling behavior (Johnson \& Auh, 1998). Therefore, the authors propose the following hypothesis:

H2: The satisfaction level of complaint handling process through social media has positive impact on customer trust

In relation to product quality, we argue that when customers are satisfied with the complaints handling service provided by the company, they will be perceived that the product/service is also qualified. On other hand, customer trust would also be increased if customers are confident in the company's reliability and integrity. If it is associated with product quality, the authors argue that customer trust in the company will affect customer opinion about the quality of products/services offered by the company. Therefore, the we propose the following hypothesis:

H3a: Customer satisfaction in complaints handling process through social media has positive impact on customer opinion about the quality of the product/service provided

H3b: Customer trust in the company has positive impact on customer opinions about the quality of products/services offered by the company

e-WOM is used to find out how customers suggest, recommend, and engage in positive talk by word of mouth through internet related to product or service (Ding \& Lii, 2016). When customers have satisfying experience with the provided services and is encouraged by the ease of access to social media, customers will spread e-WOM positively via their social media account. For mobile service providers it is very important to maintain or increase market share and profitability and retain customers. To achieve these goals, increasing customer satisfaction is one of the vital tasks. Satisfaction will retain current customer and increasing the chance that they will spread the positive review thus increasing others' interest in the product/service and higher purchase probability. On the other hand, customer satisfaction directs customers to loyalty and WOM.

Perceived product quality variable is used to find out how customers value the quality of products offered to them (Bao, 2015). In this case, product quality represents the extent of the product/service to meets customers' need and expectations. We suggest that if the quality could fulfill customer requirements, then customer will disseminate positive information to others regarding the product/service. Therefore, the authors propose the following hypothesis:

H4a: The level of customer satisfaction has positive impact on e-WOM

H4b: Product quality has positive impact e-WOM

H4c: The level of customer trust in the company has positive impact on e-WOM

Consumer satisfaction is the main motivation for consumers to continue using the product/service. Increasing customer satisfaction level can reduce the number of complaints and customers who terminate using services. Repurchase is important for the company's success because the costs incurred for gaining new customers are greater than retaining existing customers. When customer had bad experience when using the 
product/service, they could stop subscribing and switching to competitors' service/product (Johnson \& Auh, 1998). Customer satisfaction with the services provided by complaints handling agents on social media has an influence on the customer's desire to reuse products services offered by the company.

Customer trust in corporation is a privilege owned by the company to maintain the continued use of the products/services offered. When customers trust in corporate services, customers will tend to be loyal and continue to use the product compared to the desire to purchase other competitors' product. Trust and commitment affect consumer intentions in repurchasing (Ding \& Lii, 2016). In complaints handling process through social media, trust can have a positive effect on customers, so they want to reuse products/services provided. Additionally, when product quality perceived by customers meet their expectations, it is more likely that they will continue to use these products. This will maintain the continued use of the product. Perceived quality and willingness to buy have a positive correlation, so the perceived quality can be used in predicting the desire to repurchase or repeat use (Fang, et al., 2016). Therefore, we propose the following hypothesis:

H5a: Customer satisfaction in complaints handling process has a positive impact on the continuous of use

H5b: Customer trust has a positive impact on the continuous of use

H5c: Product quality has a positive impact on continuous of use

\section{METHODOLOGY}

Quantitative research approach was used to answer the purpose of the study. The population of this study is the followers of a customer care twitter account of a large telecommunication company in Indonesia. This organization provide individual customer GSM card that largely used in mobile phones. Customers can use the service to make phone call, send instant message and use the internet data package. To ensure that the respondents is customer of the service and has file complaint, we search the account who had a post or tweet related to a complain and mentioned the account and asked them as the respondent. Currently the number of followers is around 250 users. The data will be analyzed using structural equation modelling and the sample size suggested by (Hair, et al., 2011) is more than 100 data.

Nine variables were introduced based on the conceptual model with 29 indicators item. The exogenous variables are the dimensions of perceived justice, namely; distributive justice (3 items), procedural justice (4 items), interpersonal justice (3 items) and informational justice (3 items). We defined five endogen variables which are customer satisfaction (4 items), trust (3 items), product quality (3 items), e-WOM ( 3 items) and continuous usage ( 3 items). Then, indicators that represent all the variables were written in a questionnaire with five Likert scale 1 to 5 ranging from "strongly disagree" to "strongly agree". Prior to questionnaires dissemination, readability test was conducted by twenty respondents to assess the clarity of the statements in the survey. Data collecting was conducted online by asking the follower of the account who had sent complaint to the account. Then, CB-SEM was used to analyze the survey result using IBM SPSS AMOS 24 and IBM SPSS Statistics 20.

\section{RESULT}

\subsection{Demographics of Respondents}

The research data was collected in five weeks and we successfully obtained 250 respondents. However, there are several invalid questionnaires and omitted from the set, resulted 238 valid responses. The demographic of the respondents is shown in Table 1.

Table 1. Respondents' Demographic

\begin{tabular}{|c|c|c|c|c|c|c|c|}
\hline \multicolumn{2}{|c|}{ Variable } & \multirow{2}{*}{$\frac{\text { Total }}{140}$} & \multirow{2}{*}{$\frac{\text { Percent. }}{58.82 \%}$} & \multicolumn{2}{|r|}{ Variable } & Total & Percent. \\
\hline \multirow{2}{*}{ Gender } & Male & & & \multirow[t]{7}{*}{ Education } & Primary Sch. & 5 & $2.10 \%$ \\
\hline & Female & 98 & $41.18 \%$ & & Junior High & 112 & $47.06 \%$ \\
\hline \multirow{5}{*}{ Age } & $<=20$ years & 46 & $19.33 \%$ & & High School & 9 & $3.78 \%$ \\
\hline & 21-30 years & 132 & $55.46 \%$ & & Diploma & 22 & $9.24 \%$ \\
\hline & $31-40$ years & 52 & $21.85 \%$ & & Bachelor & 84 & $35.29 \%$ \\
\hline & 41-50 years & 7 & $2.94 \%$ & & Master & 6 & $2.52 \%$ \\
\hline & $>50$ years & 1 & $0.42 \%$ & & & & \\
\hline
\end{tabular}




\subsection{Reliability and Validity Testing}

Convergent validity test is conducted by assessing the factor loading value of each indicator. The factor loading value that is more than 0.50 is an acceptable minimum value (Hair, et al., 2011). If the value is less than the threshold then the elimination of indicators is carried out as in the previous stage. After all the loading factors fulfill the threshold, we continued to the internal construct reliability test. Reliability testing is conducted by evaluating the Average Variance Extracted, Construct Reliability, and Cronbach's Alpha values (Table 2). Discriminant validity tests was conducted by comparing the AVE square root values with correlation values between variables. It can be fulfilled if the square root value is greater the correlation value with other variables. The goodness of fit (GFI) value is 0.846 and the model is statistically declared to be good fit.

Table 2. AVE, CR, CA Values

\begin{tabular}{lccc|cccc}
\hline Variables & AVE & CR & CA & Variables & AVE & CR & CA \\
\hline e-WOM & 0.75 & 0.9 & 0.875 & Interpersonal_Justice & 0.653 & 0.849 & 0.959 \\
Trust & 0.826 & 0.905 & 0.882 & Procedural_Justice & 0.711 & 0.907 & 0.936 \\
Continuous_Usage & 0.626 & 0.77 & 0.849 & Distributive_Justice & 0.725 & 0.885 & 0.925 \\
Customer_Satisfaction & 0.734 & 0.917 & 0.906 & Perceived_Product_Quality & 0.685 & 0.867 & 0.818 \\
Informational_Justice & 0.716 & 0.883 & 0.894 & & & & \\
\hline
\end{tabular}

\subsection{Hypothesis Testing}

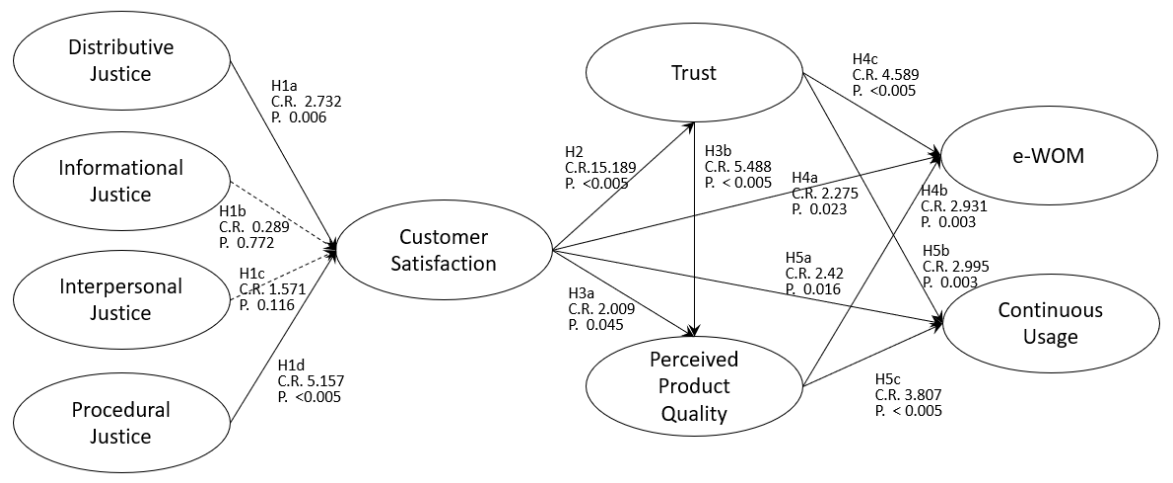

Figure 2. Hypothesis Testing Result

At this stage hypothesis testing will be carried out. Testing this hypothesis is done by measuring the level of significance of the relationship between variables in the structural model. For this significance test, the author uses the value of critical ratio (C.R) and p-value from the results of the regression weight bootstrapping as a reference. The p-value that must be fulfilled is less than (5\%) or $\mid$ C.R $\mid>1.96$, which means that exogenous constructs have a significant effect on endogenous constructs at a $5 \%$ significance level with a 5\% probability of error (Hair, 2014). Figure 2 shows the result of the hypothesis testing. Two hypotheses were rejected which was $\mathrm{H} 1 \mathrm{~b}$ and $\mathrm{H} 1 \mathrm{c}$ with $\mathrm{p}$ value more than 0.005 .

\section{ANALYSIS AND DISCUSSION}

Four hypotheses were proposed in evaluating perceived justice and customer satisfaction. The results show that distributive and procedural justice have positive influence towards customer satisfaction. However, it is not affected by procedural and interpersonal justice. In case of distributive justice, giving complementary would influence the level of customer satisfaction. When customer experienced service failure, the refund system will make customers feel satisfied with the complaints handling process. This is in accordance with the research conducted by (Ding \& Lii, 2016), distributive justice such as discounts and refunds given by companies to customers after service recovery gives a higher level of satisfaction. Additionally, procedures 
that are fair to customers will affect the level of customer satisfaction. The procedure for handling complaints that includes the process, speed and timeliness in resolving complaints is very important. It is implied that customers want their complaints to be resolved more quickly and precisely. They will not want to wait long for the problem-solving process. In handling complaints through social media, this can be attributed to the speed and accuracy of responses from the customer service. This result is also consistent with the research by (Ding \& Lii, 2016) and (Brock, et al., 2013), that procedural justice includes timeliness, accessibility, process control, and flexibility will increase consumer satisfaction. Informational and interpersonal justice in the other hand, are found to be not significantly affect customer satisfaction. In this case it can be explained that the customer does not need information that is really detailed about the service disruption that occurred. And the utilization of social media as the complaint handling communication tools do not required direct meetings with customer. Therefore, based on the results of this study, the fact that interpersonal justice is the attitude of the agent handling complaints is not too influential on the level of satisfaction felt by the customer.

From the results of hypothesis testing, it was found that the satisfaction in complaints handling process affected customer trust. When customers are satisfied with company's response regarding the complaint, the level of customer trust toward the company also increases. The factor of customer satisfaction with complaints handling process influences customer opinions about the quality of the service provided. They will assume that the quality is appropriate. Customer trust in the company also has a positive influence on customer opinions about the quality of services offered. This means that when the customer uses the service accompanied by trust towards to company they will perceived that the quality of the product is acceptable. The level of customer satisfaction with the services of a provider has a significant influence on e-WOM. Customer satisfaction will produce positive e-WOM about their experience. In addition, product quality influences e-WOM. This can be interpreted that acceptable service quality will affect the customers' desire to provide e-WOM positively. The level of customer trust in the company has a significant influence on e-WOM. This means that if the customer confidence level increases, the customer may spread positive information through e-WOM. When customers have trust in the corporation, then most likely customers will spread positive information about the corporation, especially in regard of the complaint handling case through social media.

Customer satisfaction with complaints handling services has a significant influence on continuous usage. When the customer is satisfied with the service of a complaint handling process, the customer's desire to use the service will increase or continuing the consumption of current service. Meanwhile, customer trust also affects the customer's intention to reuse. And, product quality has a positive impact on customer's intention to repurchase. This means that perceptions of good product quality will trigger customers to repurchase or continuing current service. Thus, in complaint handling process when it is typically a disadvantageous condition for the company, it could be managed so that the negative possible impact would turn into positive impacts where customer will repurchase or continuing current service and company could be advantaged by the positive e-WOM that would bring new customer in.

\section{IMPLICATION}

The theory of Perceived Justice defined four applicable justice which are distributive justice, informational justice, interpersonal justice, and procedural justice. The results of this study indicate that customer satisfaction is influenced by perceived justice which are distributive justice and procedural justice. We argue that in the context of handling complaints through social media, customers prioritize the time and accuracy in handling complaints (procedural justice) and are supported by compensation given to customers (distributive justice). In addition, the results of the study show that perceived product quality can be added to the e-WOM concept and continues usage. In previous research, the concept of e-WOM and continues usage (repurchase Intention) was only influenced by customer satisfaction and trust.

For practical implication, company will want to compensate and resolved the problem quickly when customers report their problem by using social media platform to increase customer satisfaction. So, in handling complaints, companies can prioritize distributive justice, which is providing appropriate compensation and procedural justice in the form of speed and accuracy in resolving customer complaints. This can be done by simplifying complaints handling. Customers who are satisfied with the services of tend to repurchase products and be loyal to the company. This loyal customer will help spread positive information through e-WOM through social media, which is a free and effective marketing tool. 


\section{CONCLUSION}

The results of the study statistically prove that distributive justice and procedural justice are proven to affect customer satisfaction in complaint handling process. Meanwhile, informational justice and interpersonal justice are not proven to affect customer satisfaction. Of the two proven dimensions of justice, the most influential one is procedural justice. This means that in handling complaints process, customers prefer accuracy and promptness when they experience such condition. Results also show that the satisfaction of handling customer complaints affects customer trust and the perceived quality of the services offered by the company. Also, trust and perceived service quality affect the intention to spread e-WOM and reuse the service. When customers have trust in the corporation, it more likely that customers will spread positive information about the corporation, especially through social media. In addition, perceptions of good product quality will trigger customers to repurchase or continue use.

\section{ACKNOWLEDGEMENT}

This study is supported by the Universitas Indonesia Publication Grant (PIT9) entitled "Implementasi Sistem Enterprise di Indonesia" with contract number NKB-0012/UN2.R3.1/HKP.05.00/2019

\section{REFERENCES}

Bao, J., 2015. The Impacts of E-service Quality on Customers' Repurchase Intention in Platform Online Retailing: An Empirical Investigation. s.l., AIS Electronic Library.

Brock, C., Blut, M. \& Evanschitzky, H., 2013. Satisfaction with complaint handling: A replication study on its determinants in a business-to-business context. Germany: Zeppelin University, Corporate Management and Economics.

Ding, M.-C. \& Lii, Y.-S., 2016. Handling online service recovery: Effects of perceived justice on online games. Telematics and Informatics, 33(4), pp. 881-895.

Fang, J., Shao, Y. \& Wen, C., 2016. Transactional quality, relational quality, and consumer e-loyalty: Evidence from SEM and fsQCA. International Journal of Information Management, Volume 36, p. 1205-1217.

Hair, 2014. A Primer on Partial Least Squares Structural Equation Modeling (PLS-SEM). European Business Review, Volume 26, pp. 106-121.

Hair, J. F., Sarstedt, M., Hopkins, L. \& Kuppelwieser, V. G., 2011. PLS-SEM: Indeed a Silver Bullet. Volume 19, pp. 139-152.

Hennig-Thurau, T., Gwinner, K., Walsh, G. \& Gremier, D., 2004. Electronic Word-Of-Mouth via Consumer-Opinion Platforms: What Motives Consumers to Articulate Themselves On The Intenet?. Journal Of Interactive Marketing, 18(1), pp. 28-52.

Johannsen, F. \& Zellner, G., 2015. Introducing a Professional Complaint Management: The Case of a Fleet Management Company. Jerman: University of Regensburg.

Johnson, M. D. \& Auh, S., 1998. Customer Satisfaction, Loyalty, and the Trust Environment. Advances in Consumer Research, Volume 25, pp. 15-20.

Karatepe, O. M., 2006. Customer complaints and organizational responses: the effects of complainants' perceptions of justice on satisfaction and loyalty. International Journal of Hospitality Management, 25(1), pp. 69-90.

Kotler, P., 2009. Manajemen Pemasaran. 13 ed. Jakarta: Erlangga.

Nikbin, D., Marimuthu, M. \& Armesh, H., 2012. Perceived justice in service recovery and switching intention: Evidence from Malaysian mobile telecommunication industry. Management Research Review, 35(3/4), pp. 309-325.

Park, D. \& Kim, S., 2008. The Effects of Consumer Knowledge on Message Processing on Electronic Word-of-Mouth via Online Consumer Reviews. Electronic Commerce Research and Applications, Volume 7, p. 399-410.

Tax, S. S., Brown, S. W. \& Chandrashekaran, M., 1998. Customer Evaluation of Service Complaint Experience: Implications for Relationship Marketing. Journal of Marketing, 62(2), pp. 60-76 .

Wirtz, J. \& Matilla, A. S., 2004. Consumer Responses to Compensation, Speed of Recovery and Apology after a Aervice Failure. International Journal of Service Industry Management, 15(2), pp. 150-166. 